\title{
Structure for a Museology Course in Brazil
}

\author{
M. M. Duarte Cândido
}

University of Liège,

7, Place du 20-Août, Liège, B- 4000, Belgium

For citation: Duarte Cândido, M. M. 2018. Structure for a Museology Course in Brazil. The Problems of Museology, 9 (2), 172-184. https://doi.org/10.21638/11701/spbu27.2018.204

This article presents the primary theoretical and conceptual framework in which the elaboration of the pedagogical project for the 2010 Museology undergraduate program at the Federal University of Goiás (UFG), Brazil is based. It discusses the amplified concept of a museum, the place of Museology as a discipline of Applied Social Sciences and the specific research content within Museology. A moment of great expansion of the higher education in Brazil provided context for the creation of this programme, through a Federal Government project entitled Program to Support Restructuring and Expansion Plans of Federal Universities (REUNI) and also by the UFG's initiative through its Faculty of Social Science and Anthropological Museum, which has become the main laboratory for the new Museology course. We present the structural concepts of this course as museum, Museology as a Applied Social Science field and other discussions which were important to choose the disciplines offered in the program, if we consider the existence of a General Museology, a Special Museology and an Applied Museology, and also the existence of a museological chain of operation based on cultural heritage safeguard and communication, in opposition to the hegemonial program structure considering preservation, research and communication. In our view, the chain of operation implies the existence of museological applied research integrating it parts (which are documentation, conservation, expography and cultural educational action), and avoid to explicitly mention research because it can be misunderstood with systematic investigation and study of collections, which are also done inside the museum, but belongs to others fields' knowledge, external to Museology. We also try to demonstrate how the UFG's structure of Museology Course has privileged to prepare students for applied research in Museology, avoiding overlapping contents from other knowledge fields which also make researches and interpretations of museum collections.

Keywords: Museology, Brazilian Museology, Museology course, Federal University of Goiás, discipline, applied social sciences field, applied research.

\section{Introduction}

The following text presents the principal theoretical-conceptual framework in which the elaboration of the pedagogical project for the Bachelor Course in Museology at Goiás Federal University (UFG) is based. The program was intensely developed over the course of 2009 and began in 2010.

Goiás, a state situated in the central region of Brazil, has the nation's capitol (known as the Federal District), Brasília, embedded in it's territory. Goiânia, the capitol of Goiás, is about 200 kilometres from Brasília. It is a planned city founded in 1933 that now houses 2.5 million inhabitants.

(c) Санкт-Петербургский государственный университет, 2018 
The Brazilian Institute of Museums works with about 3000 museums in Brazil, 218 of those being in the Center-West region (IBRAM, 2011). According to the State Department of Education, Culture and Sports of Goiás, SEDUCE, the state of Goiás has 61 museums. Among these are public city, state (four of them belonging to SEDUCE) and national museums as well as private ones. It is known that there are some inaccuracies in these numbers, either because of the dynamics that result the imposition of constant updating (although the publication used as a reference here is almost a decade old) or by the fact that IBRAM accepts those institutions that are self-declared museums. However, what is important to emphasise here is the accelerated growth in the number of museums in the country even though news of closures also occurs, especially linked to the economic crisis. The growth in the number of institutions occurs along the axis of economic development, in the south-east and south regions of the country, although other models and processes such as museum-like Memory Spots ${ }^{1}$ present other patterns and multiply in more impoverished areas of the country, such as the northeast region.

According to Ulpiano Bezerra de Meneses "in the $21^{\text {st }}$ century, museums will not be anachronistic and nostalgic spaces, afraid of being contaminated with the virus of mass society; rather, they may constitute extraordinary channels of knowledge and examination of that same society. They will thus be big pockets for personalised rhythms of fruition and for the formation of critical consciousness, which can not be mass produced"2.

The pedagogical project that gave rise to the Museology course at UFG, affirmed that "Despite the significant number of institutions concerned with the preservation of national and local cultural heritage and memories, the number of Museology courses in Brazil whose curriculum focuses on the training of professionals specialized in the management of cultural heritage and the technical know-how of the museum studies field is inexpressive. There are only twelve courses (11 bachelor's and one master's degree) (...) besides the deactivated specialisation courses in Museology such as the USP/Archaeology and Ethnology Museum, UFG and UFRGS"3.

During the administrations of Lula da Silva and Dilma Rousseff (Workers' Party) the Brazilian Government implemented a public policy aimed at expanding access to higher education in Brazil, notably night courses which allow the labouring class to study after their days work, REUNI ${ }^{4}$. With the incentive of this public policy and other initiatives, the number of Museology courses in Brazil went from two bachelor's degree programs and fifteen speciality courses (that were never recognized by the law that regulates the $\mathrm{Mu}$ seologist profession) throughout the $20^{\text {th }}$ century to sixteen bachelor's degree programs distributed across the country, five master's degree programs, one $\mathrm{PhD}$ program and one technical course in museums by 2018 , meaning an opportunity for academic training at all levels.

\footnotetext{
${ }^{1}$ Memory Spots are community initiatives linked to the preservation of memory but especially of people's lives, which have many points in common with museums, and can be characterised as processes of musealisation, performing various aspects of the museum's chain of operation, but which do not necessarily desire to become institutionalised or called museums. See: Instituto Brasileiro de Museus [Ibram]; Organização dos Estados Iberoamericanos [OEI], 2016.

2 Meneses, 2005. P. 20.

${ }^{3}$ Lima et al., 2011.

${ }^{4}$ Program to Support Restructuring and Expansion Plans of Federal Universities, created in 2007, under the Lula da Silva government, closed in December 2012.
} 


\section{The local context}

In 2006, during the Second Forum of Brazilian University Museums held in Belo Horizonte, the document Diagnosis of University Museums of the Central-West Region was presented, prepared by a commission of university museum managers from the region and representatives of the National Historic and Artistic Heritage Institute (IPHAN) ${ }^{5}$. Besides the Centre-West, the other Brazilian regions also produced and presented their respective diagnoses.

The research that substantiated these documents detected, among other aspects, the importance of museum institutions in the universities of the country because constitute research spaces, besides being laboratories for complementary activities of several undergraduate and postgraduate courses.

Despite the growing importance of university museums and museums in general in the contemporary world, they still have many weaknesses. Among these, the one that most jeopardises the management of cultural and scientific assets is the lack of qualified personnel.

To meet the demand for professionals specialised in the field, the UFG Anthropological Museum held a specialisation course in Museum Studies from 2000 to 2002, academically linked to the UFG Faculty of Human Sciences and Philosophy. The result was the training of 18 specialists, including professionals who work in museums in the interior of the State of Goiás. The teaching staff of the course was composed of UFG professors and museology professors from other Brazilian universities. The final report presented by the Graduate Committee of the Department of Social Sciences for Matters of the Specialization Course in Museology recommended the continuity of the course which, however, did not occur. The 1998-2001 Management Report of the Anthropological Museum of UFG by prof. Marco Antonio Lazarin, on the subject of the specialisation course in Museology, also recommended the formation of new classes, as the course "has proven to be an excellent field of critical training regarding Museums, as well as providing training for professionals in an extremely underprivileged area in Goiás"6.

Considering that in the mapping of Brazilian museums, carried out by DEMU / IPHAN, the Central-West and North regions did not have any undergraduate degree in $\mathrm{Mu}-$ seology by August $2009^{7}$, but had a significant number of museums and cultural centres, it was considered opportune to create a course in Museology at the Federal University of Goiás that would join them in training professionals specialised in working within the different areas of Museology: conservation, documentation, presentation and exhibition practice, educational action, management and evaluation of museums.

At that moment, the Anthropological Museum of the UFG, created in 1969, was almost forty years old and was consolidated in the region as a reference in the museological field, as much for the richness of its archaeological and ethnographic collections, as for the tradition of its investigations and educational and cultural actions. In this trajectory, it built Conservation and Archaeology laboratories, through funding from development

${ }^{5}$ It worth noting that the roots of IBRAM are at IPHAN since the Department of Museums and Cultural Centres (DEMU / IPHAN) originated the creation of IBRAM, which gained autonomy as a new autarkical institution of the Federal Government in early 2009.

${ }^{6}$ Lima et al., 2009.

${ }^{7}$ After the implementation of REUNI, the University of Brasília and the Federal University of Pará proposed the creation of a degree in Museology, both beginning this year. 
agencies, such as Vitae Foundation and IPHAN, as well as financing from private initiatives linked to archaeological salvage projects. In 2006 the Museum inaugurated a new long-term exhibition, Lavras e Louvores.

Since then, there has been an expansion of all the activities of the Museum, especially those that result from the reopening of the long-term exhibition and from winning grants from funding agencies for research projects and modernisation of its equipment and services. Furthermore, the Anthropological Museum was involved with multiple activities in accordance with the cultural and museological policies of the Ministry of Culture, such as joining the Brazilian Museum System and participating in the programming of the Ibero-American Year of Museums. This expansion, linked to the revitalisation process, demanded professionals specialised in the different areas of knowledge of the museological field on a daily basis.

At the same time, the Anthropological Museum also worried about external demands to assist not only the creation of museums but also to qualify the professionals of museum institutions in various cities in Goiás. The frequency and volume of these demands indicated that a degree in Museology would attend to a lack of training in the museological workforce as well as an expansion of activities related to the field of culture in its broadest sense.

Within the UFG the proponents of the new course were the Faculty of Social Sciences (FCS) and the Anthropological Museum. The first, because of its team of anthropologists committed to the creation of this undergraduate degree, and moreover, as the professionals who would be responsible for the disciplines in Anthropology included in the graduation in Museology. Furthermore, FCS anthropologists had the experience of having been recruited systematically to manage and work at the Anthropological Museum since its inception:

"The fertile interaction between the FCS and the Anthropological Museum creates an extremely favourable context for the implementation of an undergraduate course in Museology at UFG. The course will be linked academically to the FCS and will operate within both the University and the Museum. To ensure an excellent intellectual interaction between students and professors from related areas, such as Social Sciences, Philosophy and History, the theoretical content of the course will be offered at the Samambaia Campus, while the practical coursework will be ministered at the Anthropological Museum so that their collections, laboratories, exhibitions and other areas of activity can become laboratories for the practical disciplines required of a course of this nature"8.

At the time, there was also the expectation of the re-establishment of the State Museum System, which would host the public policies to be implemented in the museums and cultural centres under its coordination and, in turn, would conduct the dialogue with the National Museum System of the Ministry of Culture. In practice, this re-establishment was attempted but did not take place, and the museum field in the state of Goiás continues to have some weaknesses from an institutional point of view.

According to its proponents, "In the medium term, and internally at the University, the Museology course would mainly contribute to making the Anthropological Museum increasingly able to fulfill its mission of being a reference in the museological field of the Centre-West. Also, it would provide specialised teams to work in the other spaces at the

\footnotetext{
${ }^{8}$ Lima et al., 2009 .
} 
UFG with a museum vocation, such as the Planetarium, the Gallery of the Faculty of Visual Arts, the Herbarium, the Archives Information and Documentation Centre, the ICB Morphology Museum, among others, so as to enable the exercise of this vocation in an increasingly professional and competent manner"

It is noteworthy that the different spaces and collections considered to have a museological vocation at the UFG, whether or not they are called a museum, were brought together under the name of a new institution created in 2016 with the name, Museum of Sciences, a poly-nucleated museum, designed as a network that integrates, especially through a shared database and exhibition projects, the pre-existing collections and initiatives. Moreover, several students of the Museology course participated in different stages of the museum implementation, notably in the registry of items from the various collections of the university in the Tainacan Database, created by the UFG.

\section{The theoretical-conceptual structure of the course}

The curriculum proposed at the time of the creation of the UFG Museology course was based on the concepts of Museology as a field of Applied Social Sciences and the museum as a service to society. For an understanding of the social role of museums and their work as channels of communication and education the following primary documents were mentioned:

UNESCO Regional Seminar on the Educational Role of Museums (Rio de Janeiro, Brazil 7-30 September 1958);

Round Table on the Development and the Role of Museums in the Contemporary World - document prepared at the end of the Round Table of Santiago, on the Role of the Museum in Latin America (Santiago, Chile, 1972);

Declaration of Quebec - Basic Principles of a New Museology 1984, inaugural letter of MINOM - International Movement for a New Museology (Quebec, 1984);

Declaration of Caracas, ORCALC-UNESCO, ICOM Venezuela, Caracas, Venezuela, February 1992, final document of the Seminar "The Mission of Museums in Latin America Today: New Challenges" (Caracas, 1992).

In addition to these documents, it is possible to note the influence of the International Council of Museums' (ICOM) production, notably its Committee for Museological Theory (ICOFOM), the Brazilian production arising from the various Museology courses at undergraduate and postgraduate levels (lato and stricto sensu) and the publications in Portuguese as Cadernos de Sociomuseologia of the Lusophone University of Humanities and Technologies and the former DEMU / IPHAN, now IBRAM.

Among the guidelines of the Brazilian Institute of Museums, the Statute of Museums was highlighted as one of the guiding landmarks of the proposed program of studies, for it's understanding of the need for Museology courses to prepare professionals capable of conducting museums in the process of adaptation to contemporary demands, among them, the preparation and implementation of the Museological Plan.

\footnotetext{
${ }^{9}$ Lima et al., 2009.
} 
The existence of General Museology, Special Museology and Applied Museology ${ }^{10}$ was taken as the epistemological basis concerning the choice of disciplines united with the understanding that undergraduate education should allow students to understand their role in different types of museums and, in the future, as a professional, adapt to a labour market formed by an immense diversity of museological models, musealisation processes and types of collections. For these reasons, the proposed program of study focused mainly on General Museology and Applied Museology. Special Museology, which refers to different museological texts and contexts, namely specific types of museums and also distinct social realities (contextual relationships), would be experienced during technical visits and case studies carried out throughout the course, and even more in-depth through the student's individual choices in internships, 'freely elective group of disciplines' (NLs) and research to elaborate the graduation dissertation.

In General Museology we contemplate subjects related to Museological Theory, the History of Museums and the Management of Museums. In regard to Applied Museology, there is an equally distributed class load between Safeguarding (Documentation / Conservation) and Cultural Heritage Communication (Expography / Educational-Cultural Action). In other words, the proposed structure of the curriculum envisions a balance between these different facets of the museological chain of operation and also encompasses the Planning and the Evaluation of the museums or the musealisation processes (figure 1).

\section{General Museology:}

1) Museological theory

2) History of museums

3) Museums management

Special Museology:

Museological text and context

Applied Museology:

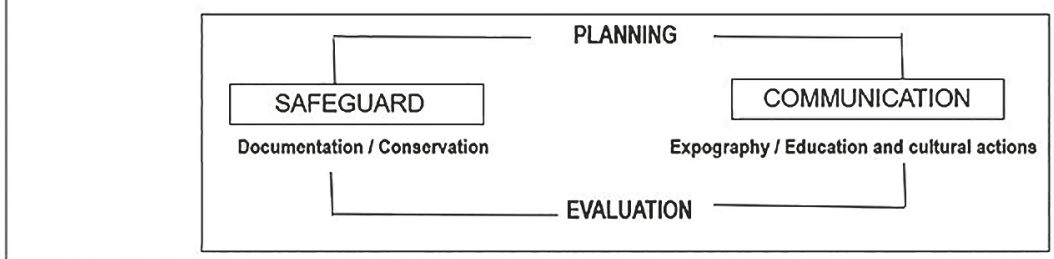

Fig. 1. Structure of the field of Museology ${ }^{11}$. It brings together elements of the Referential Framework of Bruno's Discipline of Museology ${ }^{12}$, which in turn are based on frameworks such as those of Rússio ${ }^{13}$ and Sofka ${ }^{14}$

\footnotetext{
${ }^{10}$ Lewis, 1981. P. 74.

${ }^{11}$ Duarte Cândido, 2014a. P. 20.

12 Bruno, 1996. P. 35-36.

13 Rússio, 1983 apud Bruno, 2010. P. 131.

14 Sofka, 1980 apud Hernández-Hernández, 2006. P. 142.
} 
These disciplines are the backbone of the proposed curriculum, considering that they are part of the so-called Essential Field of Museology. The other subjects also touch on the Field of Interlocution and Field of Projection of Museology $y^{15}$, but without losing sight of their specificity as a study of the specific relationship between man and object in a scenario ${ }^{16}$ (figure 2, 3).

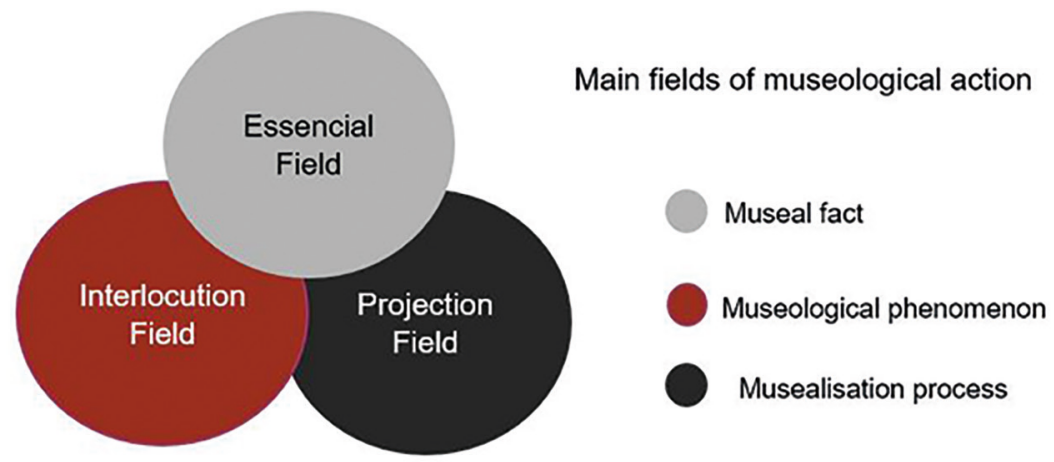

Fig. 2. Main fields of museological action ${ }^{17}$

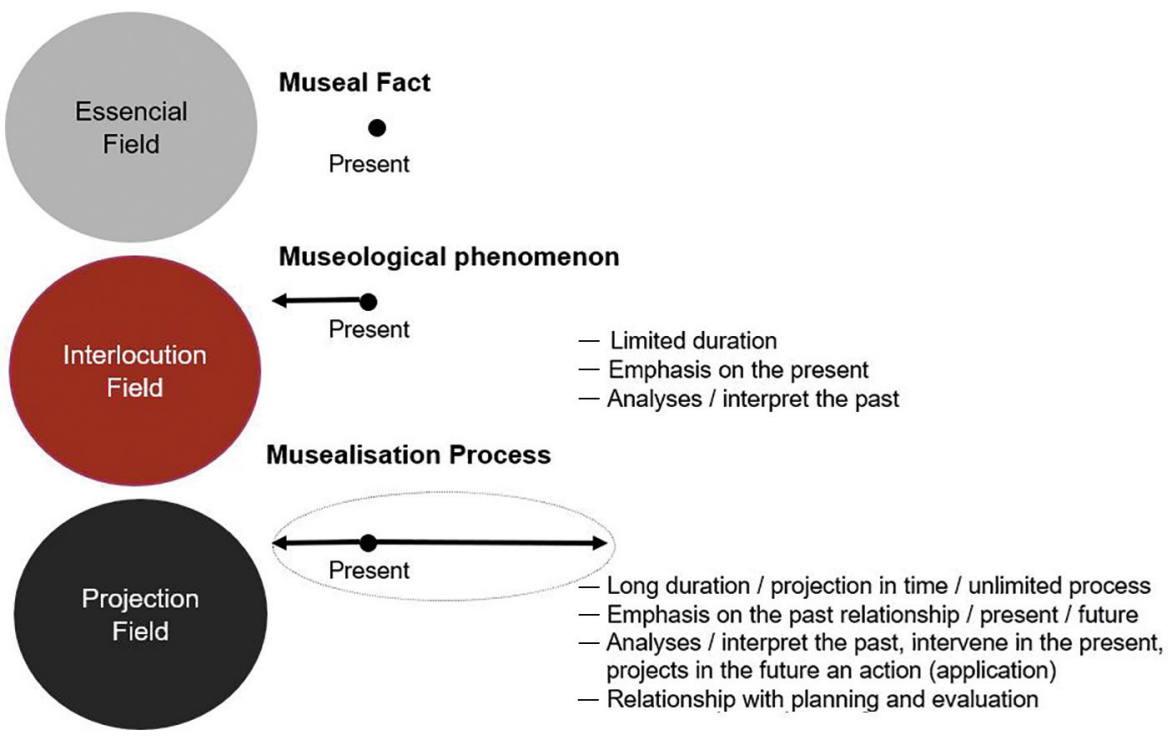

Fig. 3. Museum Fact / Museum Phenomenon / Musealisation Process in Dialogue with the Essential Fields of Interlocution and Projection of Museology $y^{18}$

\footnotetext{
15 Bruno, 2004.

16 Rússio, 1981.

17 Bruno, 2008, apud Duarte Cândido, 2014a. P. 60.

18 Duarte Cândido, 2014a. P. 61.
} 
The undergraduate course in Museology at UFG was conceived in the baccalaureate modality, with in-person, theoretical and practical classes. It belongs to the area of Applied Social Sciences and academically is linked to the Faculty of Social Sciences (FCS-UFG), where the theory classes take place. Laboratory and practical classes take place at the Anthropological Museum and other spaces with collections and museological potential at UFG. These spaces at UFG, as well as other museums linked to the Goiás State System of Museums, constitute a field of internship for the Museology student so that they can refine their museological knowledge in different types of museums. The FCS-UFG recommended to reduce the total course workload, initially projected at 2,768 hours, to the minimum required by the Ministry of Education, arriving at the latest version of 2,404 hours. This decision forced the removal of some mandatory subjects thus becoming elective courses, as well as the merger among courses of similar content to have a single workload. In the same way, the number of vacancies initially projected at 50 incoming students per year was reduced to 40 at the opening of the course, and later to 30 , adjusting to the expansion of the offer at the national level and the more realistic scenarios of demand.

The set of theoretical and practical disciplines is articulated in such a way as to guarantee that the graduate, in his professional practice, does not separate his practical activities from the reflection on them and on his place as a social worker, as recommended by Rússio. The curricular matrix foresees disciplines to be offered by the Faculty of Social Sciences and other Academic Units at the UFG, to guarantee the interdisciplinarity indispensable to the analysis of the plurality of forms of museological phenomenon in the current world.

The disciplines offer general humanistic content and other content specifically related to the identification, analysis and establishment of technical and scientific procedures for the qualification of the relation of society to its cultural heritage, that is, to the fundamental problems of Museology, evoking Bruno (1996). It is through the domain of this content that the action and reflection of the professionals of the field will take shape and will materialise in significant museological activities for society, from those that concern the preservation of cultural and natural goods to the extroversion of these goods; from exhibitions to educational-cultural actions.

At UFG, the disciplines called 'common group of disciplines' (NC) are those that provide the professional training of the field, in this case, Museology, and they are all mandatory. These disciplines should guarantee the training of skills capable of allowing the museologist to master his field of knowledge. The subjects are distributed, as follow:

\author{
History of Museums \\ Introduction to Museology \\ Museology I \\ Museology II \\ Museology III \\ Safeguarding Cultural Heritage I - Museological Documentation \\ Safeguarding Cultural Heritage II - Preventive Conservation and Security \\ Safeguarding Cultural Heritage III - Registration and Information Management \\ Systems Applied to Museums and Cultural Heritage \\ Safeguarding Cultural Heritage IV — Laboratorial Practices of Preventive Conserva- \\ tion
}


Cultural Heritage Communication I - Education and Cultural Action

Cultural Heritage Communication II - Expography

Cultural Heritage Communication III - Non-formal Education Practices Applied to Museums

Cultural Heritage Communication IV - Design and Assembly of Exhibition

Museum Management and Evaluation

Public Studies and Evaluation

Museum Spaces and Museum Architecture

Museology Research Seminars

Research Methodology Applied to Museology

Graduation Dissertation

Curricular Internship I

Internship II

The 'specific group of disciplines' (NE) may be shared with other courses and be mandatory or elective. Following are the 'specific group of disciplines', the last eight being elective:

Introduction to Anthropology

Anthropology and Cultural Heritage

History and World Cultural Heritage

History and Cultural Heritage of Brazil

History and Cultural Heritage of Goiás

History of Art I

Object Theories and Material Culture Studies

Special Topics in Museology I - Museology Applied to Collections ${ }^{19}$

Anthropology and Museums

Cultural Heritage Legislation and Ethics

History of Art II

Museology and Brazilian Art

Special Topics in Museology II

Processes of Musealisation, Tourism and Development

Natural, Scientific and Technological Heritage

Anthropology of Aesthetic Expressions

Museology - Disciplinary Interfaces

Museological Text and Context - Technical and Diagnostic Visits

To increase the interdisciplinarity within the Faculty of Social Sciences, 'special topics disciplines' were created in Anthropology, Sociology and Political Science, and students of Museology may attend them. Likewise, students of Social Sciences may attend the 'special topics disciplines' created in Museology. Students must take at least five electives. We will not detail each discipline, but next, we present a table of its distribution per semester, in which the course's sequencing and structure are evident (figure 4).

${ }^{19}$ Different versions of this discipline are offered, such as Museology applied to collections of contemporary art, archaeological collections or scientific and technological collections, among others. 


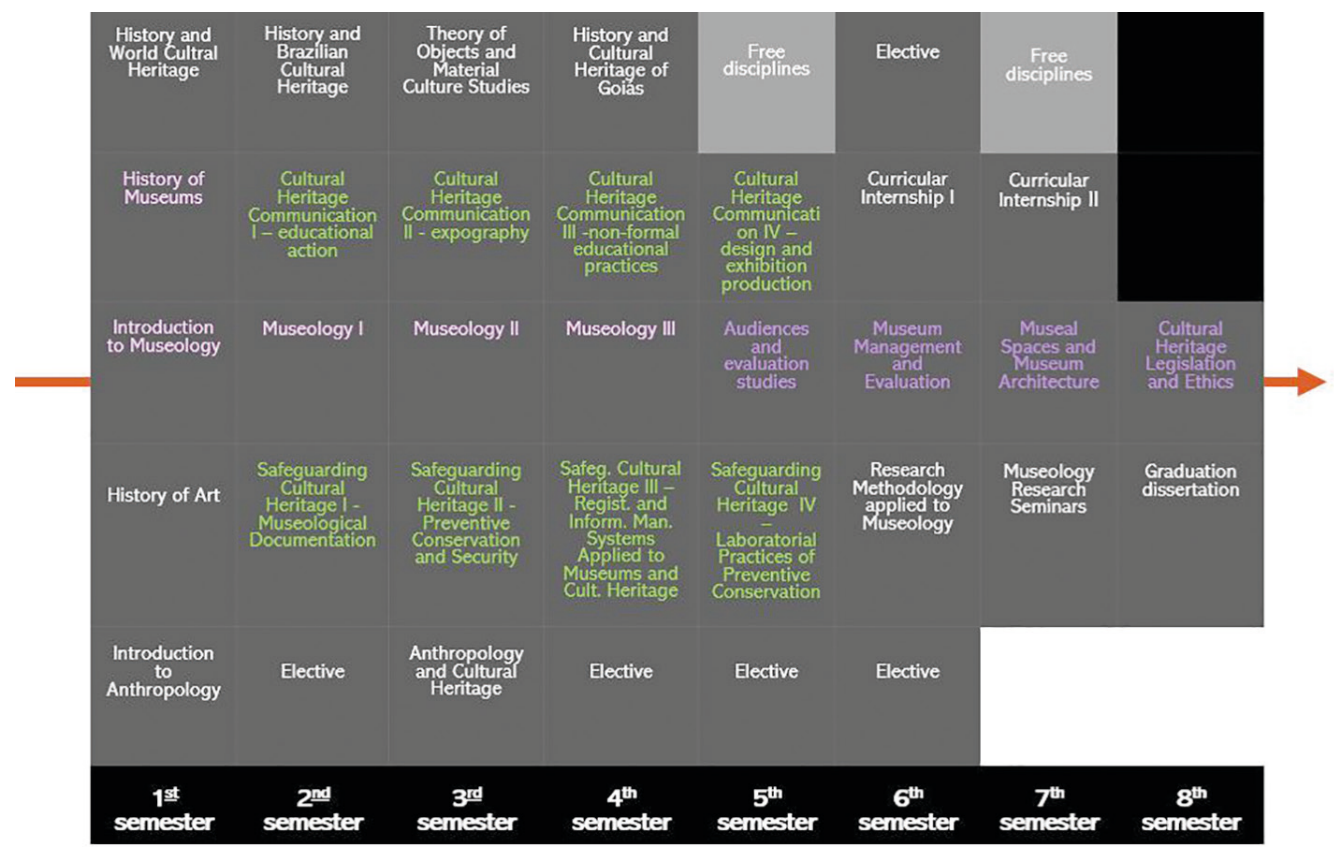

Fig. 4. Distribution table of subjects for the bachelor of Museology at UFG

The UFG also has a type of discipline called 'freely elective discipline group' (NL) that can be chosen by students of any course (at least two NLs per student). Through their free choice, students can deepen their understanding of topics that they consider pertinent to their specific interests within Museology that were not contemplated in the program or in those in which he intends to specialise. Thus, it is possible to study 'freely elective discipline group' (NL) subjects on lighting, computer science, statistics, visual communication, collections of natural sciences, among others.

The internship is a compulsory requirement of the baccalaureate in Museology, with 128 hours distributed in two 64-hour disciplines. The museum spaces and/or collections considered to have a museological vocation at UFG are preferred places for the internship, but also other museums and cultural centres of the state are possible options. The extension of possibilities for internships outside the University aims to provide the graduate with a broader range of museum experiences, so that he can get to know the different types of museums, creating varied options for his professional specialisation. For this reason, we suggest that each internship is carried out in a different institution or among various sectors of the same institution.

A professor from the course of Museology, responsible for the discipline, directs the internship and a professional from the institution supervises the intern. Partial and final reports are prepared, in which the responsible teacher indicates his/her evaluation. Today, we can see that, as anticipated, the reduced workload of the internships is a fragility of the course, but difficult to solve due to the condition of most of the students who are busy during the day and only have the night available for the course, in hours contrary to the operation of museums. The dropout rate of the course is remains high and would be even higher if the compulsory workload was increased during times that shocked with the students' other responsibilities. 
To arrive at the total hours of the course, the student must also demonstrate the accomplishment of 80 hours of extracurricular activities, such as participation in lectures and scientific events, among others. In this way, the total course load is 2,404 hours.

\section{Final remarks}

For this text, the interest was to deepen the theoretical-conceptual aspects that structured the course. That structure is not based upon the hegemonial model identified by Peter van Mensch (1992) as PRC (preservation / research / communication), but instead it is similar to another model called by the author as CC (collection management / communication). The use of the term 'safeguard'20, rather than 'preservation', is because safeguard is a better portrait of one part of the 'musealisation process', meaning that it is equivalent to the term preservation. It is not by chance that Tomislav Sola defended in 1982, the use of the term Heritology instead of Museology, because it was not exclusive to museums anymore. Despite the author's warnings about the risk of looking heretic as one proposes news concepts beyond those already established, we return to this idea after four decades to defend the use of safeguard, instead of preservation:

"We consider, therefore, that the musealisation process occurs within a broad cultural heritage field. The selection of objects and their transformation into evidence of a reality bring about a set of memories, either tangibles or intangibles, natural or artificial, which are cultural heritage references. Once the cultural heritage references are chosen, they become part of the museological chain of operation, meaning that they get into the core of the Museology applied field - Museography. Preservation, therefore, is considered comparable to the musealisation process and can be achieved through the balanced implementation of technical-scientific procedures of safeguard and communication, which compose a chain of operation. The chain of operation carries both the responsibility over the cultural heritage constituted for the future, and the permanent and procedural communication. It must be embedded in a planning and evaluation context. This way it operates in a continuous movement, where each stage of evaluation feeds back the previous stage of planning, inspired by the idea of subsidiarity in management. The chain of operation, thus, break with the context in which management is an attribution exclusive to financial and human resources' and top-level decision-makers. The preservation or musealisation process comprises the whole process from the selection of cultural heritage references up to the moment when it is returned to society. And this process produces new cultural heritage references and interferes with new selections and new evidences of reality in a continuous movement"21.

So, we are working with a broader understanding of the field of Museology as being not only related to museums but to the processes of musealisation.

In addition, the comprehension of museological research as applied research, beyond of what is usually adopted: research is said to be one of the tasks of the museum, and it is accepted, thoughtlessly, as one of the functions of Museology, without differentiating museal research from museological research.

We understand the word museal as everything that is performed in the museum, and as museological what is pertinent to Museology. So, we consider important the use of the term Museology research always followed by an adjective, like applied research. It allows

${ }^{20}$ This term is also proposed by Cristina Bruno. For a detailed discussion, see Duarte Cândido, 2014a.

${ }^{21}$ Duarte Cândido, 2014. P. 154. 


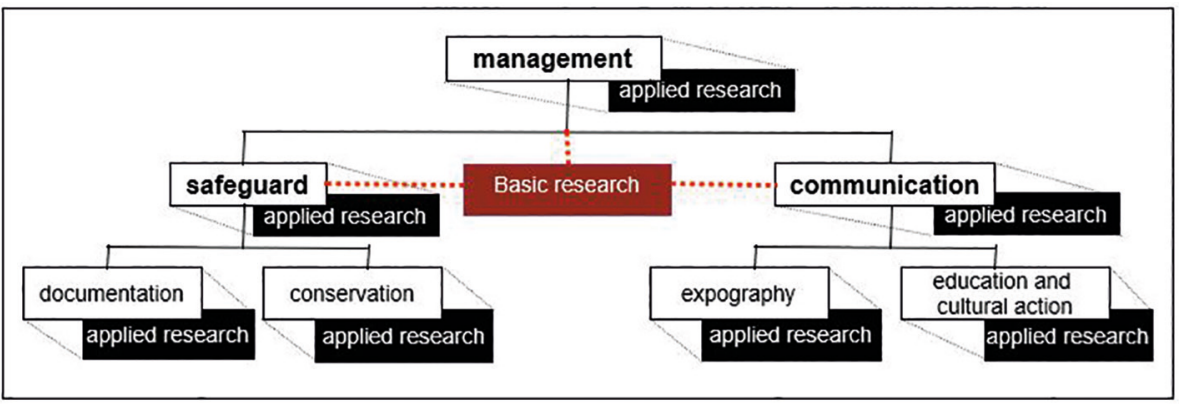

Fig. 5. Basic and applied research in musealisation processes ${ }^{22}$

differentiate it from the research in the museum, that can be applied research or basic research, pertinent to the fields related to the cultural heritage that it preserves (figure 5).

To include the research practice without any qualitative specification into the museological chain of operation would only create confusion, it would suggest safeguard and communication could be performed without research.

The clarity about which research modalities are specific to Museology, allows prioritising content in the training of Museology professionals, in order to escape from object oriented museology to functions oriented museology ${ }^{23}$.

\section{References}

Bruno M.C.O. (coord.). 2010. Waldisa Rússio Camargo Guarniéri: textos e contextos de uma trajetória profissional. 2 v. São Paulo: Pinacoteca do Estado / Secretaria de Estado da Cultura / Comitê Brasileiro do Conselho Internacional de Museus.

Bruno M. C. O. 2004. Principais campos da ação museológica. Comunicação apresentada no seminário museus e exposições no século XXI: vetores e desafios contemporâneos, 20 a 24 de julho (5p. mimeo). São Paulo: Centro Cultural Banco do Brasil.

Bruno M. C. O. 1996. Museologia e Comunicação, Cadernos de Sociomuseologia, 9. Lisboa: ULHT.

Duarte Cândido M.M. 2014a. Gestão de Museus, um desafio contemporâneo: diagnóstico museológico e planejamento. Porto Alegre: Ed. Medianiz.

Duarte Cândido M.M. 2014b. Orientações para a gestão e planejamento de museus, Coleção Estudos Museológicos, 3. Florianópolis: FCC Edições.

Hernández-Hernández F. 2006. Planteamientos teóricos de la museología. Gijón: Ediciones Trea Instituto Brasileiro de Museus [Ibram]. 2011. Museus em Números, 3 v. Brasília: Instituto Brasileiro de Museus.

Instituto Brasileiro de Museus [Ibram]; Organização dos Estados Iberoamericanos [OEI]. 2016. Memory spots: methodology and practices in Social Museology. Brasília: Phábrica.

Lewis G. 1981. The systematics of museology, its application to ICOM's international committees and the role of Icofom. Museological Working Papers/ Documents de Travail Muséologique (MuWoP/DoTraM), no. 2. Stockholm: ICOM: 74.

Lima N.C., Souza M.L.R.de, Lazarin M.A., Duarte Cândido M. M. 2009. Um curso de Museologia para Goiás: Bacharelado em Museologia da UFG. Anais do I Congresso Internacional de Museologia: sociedade e desenvolvimento. Maringá: Editora da UEM.

Meneses U. B. de. 2005. A exposição museológica e o conhecimento histórico. Betânia Gonçalves Figueiredo, Diana Gonçalves Vidal (Orgs.) Museus: dos gabinetes de curiosidades à museologia moderna. Belo Horizonte: Argumentum.

\footnotetext{
22 Duarte Cândido, 2014b. P. 35.

${ }^{23}$ Van Mensch, 1992.
} 
Rússio W. L'interdisciplinarité em muséologie. Museological. Museological Working Papers/ Documents de Travail Muséologique (MuWoP/DoTraM), no. 2. Stockholm: ICOM: 58-59.

Sola T. 1982. A contribution to a possible definition of Museology. Presented at ICOFOM Interdisciplinarity in Museology. Paris: ICOFOM. URL: http://www.heritology.com/A_contribution_to_a_possible_ definition_of_Museology_-by_Tomislav_Sola.pdf (accessed: 10.11.2018).

Van Mensch P. 1992. Towards a methodology for Museology. PhD thesis, University of Zagreb. URL: http:// xa.yimg.com/kq/groups/23466284/1995686355/name/Towards (accessed: 22.12.2017).

Received: May 15, 2018

Accepted: June 25, 2018

Author's information:

Manuelina M. Duarte Cândido - PhD in Museology, Associate Professor; manuelin@uol.com.br

\section{Структура учебной программы по музеологии в Бразилии}

\section{М. М. Дуарте Кандидо}

Льежский университет, Бельгия, В-4000, Льеж, ул. 20 августа, 7

Для цитирования: Duarte Cândido, M. M. 2018. Structure for a Museology Course in Brazil. Bonpoсы музеологии, 9 (2), 172-184. https://doi.org/10.21638/11701/spbu27.2018.204 (In English)

В статье представлены основные теоретические и концептуальные основы, на которых базируется учебная программа бакалавриата по музеологии, реализуемая с 2010 г. в Федеральном университете Гояс, Бразилия. В рамках программы предусмотрено изучение ключевых концепций музеологии, определение места музеологии как дисциплины в структуре научного знания, выявление специфики исследований, проводимых в музее. Программа создавалась в период активного развития высшего образования в Бразилии, поэтому получила поддержку в рамках федерального проекта «Программа поддержки реструктуризации и расширения учебных планов федеральных университетов» (REUNI)» и инициативы Университета Гояс на базе факультета социальных наук. Основной лабораторией и практической площадкой для ее реализации стал Музей антропологии. В статье представлена характеристика концептуальных основ данного курса, в частности подход к музеологии как прикладной социальной науке, пропагандируются другие ее аспекты, важные для обучающихся. Рассматриваются вопросы общей, специальной и прикладной музеологии, их связь с вопросами охраны культурного наследия. На наш взгляд, преподавание учебного курса по музеологии невозможно без акцента на прикладные исследования, объединяющие ее части (документирование, хранение, экспонирование, культурно-просветительскую деятельность). Сделана попытка продемонстрировать, какой вклад программа вносит в образовательную систему Федерального университета штата Гояс, как она влияет на процесс формирования у студентов прикладных навыков в области музеологии, а также научные исследования в указанной области. Структура программы исключает дублирование информации из других курсов и областей знания, способствует развитию научных исследований и новой интерпретации музейных коллекций.

Ключевые слова: музеология, бразильская музеология, курс по музеологии, Федеральный университет Гояс, дисциплина, прикладная общественная наука, прикладные исследования.

Контактная информация:

Мануэлина М. Дуарте Кандидо - д-р музеологии; manuelin@uol.com.br 